\title{
Tapestry Production in the Burgundian Netherlands, Art for Export and Pleasure
}

\author{
DAGMAR EICHBERGER
}

$\mathrm{N}$ owadays, sets of tapestries such as the David and Bathseba cycle in the Château d'Ecouen are no longer known to the general public despite the fact that they were once famous examples of Northern Renaissance art which were considered to be of historical importance and at the same time aesthetically pleasing. ${ }^{1}$ Unfortunately, these sets of tapestries are not easily accessible to the art-loving traveller, either because they are tucked away in private collections or because they are kept in less well known, specialist museums. In addition, full sets of tapestries are often not on display due to their large dimensions. ${ }^{2}$

When talking about the art and culture of the so-called Burgundian Netherlands one generally thinks of panel paintings such as Jan van Eyck's Arnolfini Wedding in the National Gallery in London or Hans Memling's Man of Sorrows in the National Gallery of Victoria and not necessarily of sets of tapestries such as Pieter van Aelst's The Acts of the Apostles or Bernard van Orley's The Story of Jacob. ${ }^{3}$ Given the fact that in the late Middle Ages early Renaissance tapestries were one of the most prestigious and highly priced art forms on the market, it is unfortunate that the study of these tapestries now plays a subordinate role in the general discourse of art history and has become almost exclusively the domain of French or Belgian specialists. Even in standard handbooks such as James Snyder's Northern Renaissance Art ${ }^{4}$ tapestries are not given the recognition they deserve in historical and aesthetic terms. This situation can be explained in part by the development of Art History as a discipline, which, since its beginnings in the nineteenth century, has been preoccupied with painting, sculpture and architecture as the most noble forms of artistic production. In the course of establishing public art museums, objects classified as Decorative Arts were generally stored and displayed separately from panel paintings and tended to be seen rather as examples of utilitarian or purely functional art than as examples of 
what is called by some 'high art' ${ }^{5}$ In the course of my paper I will show that many of these tapestries were in fact designed by the leading artists of the time and were often preferred to panel paintings by the most notable patrons of the arts such as Duke Philip the Good. While artists such as Rogier van der Weyden and Jan van Eyck undoubtedly made a major contribution to the history of painting in absolute terms, it is worthwhile to remember that the different techniques, for instance painting and tapestry making, were not practised independently from one another. I will therefore also discuss the close collaboration between the representatives from different guilds and will look at the specific circumstances under which these tapestries were produced. Apart from discussing tapestries in respect to design, production and distribution, it needs to be stressed that in this cultural environment the medium of tapestries, and not that of panel paintings, was normally chosen to depict politically significant themes. The Battle of Pavia, for instance, was not depicted in oil on wood, but was rendered in a woven image immediately after the event took place. ${ }^{6}$ It is fair to say that in major private collections of the time the important genre called History Painting can be found predominantly in the medium of woven tapestries and carries little weight in panel paintings. ${ }^{7}$ This is particularly relevant for northern Europe, where representational tapestries were the most monumental art form and fulfilled a function similar to frescoes in Italian art. Throughout the fifteenth and sixteenth centuries, tapestries were highly esteemed collectors' items which could be found in the dwellings of Kings, Dukes and Popes. Panel paintings, on the other hand, were more frequently purchased by well-to-do members of the civic bourgeoisie, for example lawyers, tax collectors, foreign merchants, guilds and religious fraternities to name only a few. ${ }^{8}$ These tapestries and panel paintings were produced in a cultural landscape which is generally called The Burgundian Netherlands. ${ }^{9}$

The Burgundian Netherlands as defined by Prevenier and Blockmans can be described as a conglomeration of disparate principalities and bishoprics once united under the rulership of the Dukes of Burgundy, a branch of the French Valois family which governed this territory from 1384 onwards. ${ }^{10}$ When Mary of Burgundy, the only daughter of Duke Charles the Bold married Maximilian I, the Burgundian line merged with the Hapsburgian line and the Netherlands were consequently governed by different family members such as Margaret of Austria and Charles V. Due to the wealth of some of the principalities especially Brabant, Hainault and Flanders the ambitious Dukes of Burgundy could compete in splendour, prestige and power with the leading courts of Europe. The area controlled by the Burgundian-Hapsburgian dynasty in the early-sixteenth century is of course no longer a geographical and political entity, but nowadays forms part of four different nations, namely France, Belgium, Holland and Luxembourg. In the fifteenth and sixteenth centuries the Burgundian Netherlands were one of 
the most densely populated areas of Europe encompassing two dozen cities with more than 10,000 inhabitants, and about six cities with more than 20,000 citizens. ${ }^{11}$ Due to their location at the junction of major trading routes, Bruges and Antwerp were significant centres of international trade with distinctly cosmopolitan populations. From the early fourteenth century onwards, the wealth of the Netherlands was founded on three principal areas, a strong agricultural base, textile production and international trade. ${ }^{12}$ After the decline of the textile manufacturing industry in the Burgundian Netherlands towards the end of the fourteenth century, several cities decided to strengthen the indigenous production of hand-woven tapestries, ${ }^{13}$ in part to protect themselves from English competition. Among the cities famous for the production of tapestries were Tournai, Arras, Bruges, Brussels and Enghien. ${ }^{14}$ The city of Arras had been one of the most important centres of production in the fourteenth and the first half of the fifteenth centuries. In Arras, for example, 59 master tapestry weavers were documented between 1423 and $1467 .{ }^{15}$ According to the 'register of admission to the great trade of Brussels', dating from 1417 to 1466 , more than 500 tapestry weavers were enrolled into the local guild of Brussels. Even if not all of these 500 artisans were master weavers, this impressive figure nevertheless testifies that Brussels had become a very active and prosperous centre of tapestry making, as has been argued convincingly by Sophie Schneebalg-Perelman. ${ }^{16}$ Due to the patronage of the Burgundian court and the concentration of talent and expertise in the city of Brussels the manufacture of tapestries became increasingly important as a luxury industry and as a product for export in the second half of the fifteenth century.

The fame of Flemish artists among European patrons goes back to the fourteenth century. At that time, however, many Flemish artists tended to migrate to the various French courts in Paris, Bourges and Dijon in order to find work. ${ }^{17}$ In the fifteenth century this situation changed due to a strengthening of the artistic production in the Burgundian Netherlands and the emergence of an active art market in the prospering cities of the Brabant and Flanders. ${ }^{18}$ Artifacts were becoming major articles of trade and export in the course of the fifteenth century and it was no longer the artist himself but the art work which now travelled to all corners of Europe. This development is reflected in the method of production as well as in the strengthening of the art market during this period, as recent research by Montias, Ewing ${ }^{19}$ and Jacobs $^{20}$ has shown in more detail.

The two most common forms of trading in artifacts were to sell from a shop or to offer goods in a rented stall at one of the big annual fairs. The permanent shop, which generally consisted of a workshop with a sales counter to the street, existed already in the fifteenth century but became increasingly popular during the sixteenth century, ${ }^{21}$ especially after some of the annual fairs had been turned into permanent markets in the second- 
quarter of the sixteenth century. A painting by Petrus Christus dating from 1449 may illustrate the notion of a permanent shop in one of its earliest visual representations..$^{22}$ Here, Saint Eloy, the patron saint of the smiths and jewellery makers, acts as a salesperson for the goods produced by members of the guild he is associated with.

Most deals between craftsmen and clients, however, were struck during the big annual fairs held at regular intervals in the major trading centres. Fairs such as the 'Pentecost' and the 'St Bavo's Fair' in Antwerp lasted for approximately six weeks and gave artists ample opportunity to display samples of their goods to an international audience of merchants and individual clients. ${ }^{23}$ As far as cloth and simple textiles were concerned these were traded in specialized markets generally called Halles, which could be found along certain streets. ${ }^{24}$ Hand-woven tapestries on the other hand formed a distinct category and could generally be found in another form of market called a Pand, either an arcaded courtyard, or cloisters or a specific house. ${ }^{25}$

In the case of Antwerp, the changing outlets for the sale of tapestries are quite well documented as the recent research by Ewing has demonstrated. $\mathrm{He}$ argues that there was a trend towards more and more specialized markets and it can be seen from the documents presented that this development equally affected the sale of tapestries in the Netherlands during the late fifteenth and early sixteenth centuries. ${ }^{26}$ The Dominican Pand which opened in 1445 was the market used for the sale and display of luxury goods, including expensive artifacts. This market was frequented by members of three different guilds, the Guild of St Eloy (gold- and silversmiths), the Guild of St Luke (painters and sculptors) and the Guild of St Nicholas (jewellers and tapestry weavers). After a dispute between the friary and the guild of Saint Luke in 1480, the painters and sculptors left the Dominican Pand and the range of goods on offer was reduced to jewellery, woven tapestries and precious metalwork. This arrangement remained in place until the early 1550s when tapestry weavers moved to an even more specialised market, the Tapestry Pand in the Schuttershoven which then formed part of a permanent, all-year-round market. ${ }^{27}$

While we are quite well informed about the trade in standardized painted and carved altarpieces such as the Antwerp Altarpiece in the National Gallery in Melbourne ${ }^{28}$ very little is known about the types of tapestries that were exhibited and sold at the annual fairs mentioned earlier. While it is highly unlikely that whole sets of tapestries such as the David and Bathseba cycle would be offered to the general public without a specific buyer in mind, it is quite reasonable to assume that smaller tapestries with popular stock images such as Saint Luke painting the Virgin would be presented to the clients who could then commission a similar tapestry directly from the craftsman. ${ }^{29}$ One of the specialities of the Brussels textile manufacture, for 
instance, was the production of such single pieces of tapestry, which could be used in private chapels, either as an altar cloth, hanging in front of the altar or as a fabric retable. ${ }^{30}$ These so-called 'Altarpiece Tapestries' often tended to be square-shaped and were generally of a relatively small size. ${ }^{31}$

Two tapestries in the Germanisches Nationalmuseum, Nuremberg, which depict The Annunciation and The Mass of Saint Gregory, can be seen as representatives of this type. ${ }^{32}$ They were both made for export to Germany as the coat of arms in the bottom left and the bottom right reveal. These altar hangings were obviously bought by representatives of two well-known Nuremberg clans, the Tucher and the Holzschuher family. As far as the subject matter and the iconography are concerned these representational tapestries draw heavily from contemporary panel painting. The decorative woven frames, which were only introduced in the last-quarter of the fifteenth century, reinforce the pictorial quality of these tapestries. The frame, which surrounds, for example, The Mass of Saint Gregory, virtually imitates a carved wooden frame including the mouldings and the mitre joints. These single tapestry pieces which are of comparably small dimensions were of a price affordable to brotherhoods, guilds and wealthy burghers. The fact that customers such as the Tucher or Holzschuher families decided to purchase a tapestry which looked like a panel painting or even copied a specific model is interesting in itself. This trend suggests a change in taste and may be explained by the desire to emulate the life-style of the Burgundian nobility who could afford to decorate whole rooms with these textile hangings. ${ }^{33}$ That the possession of large sets of tapestries was generally the privilege of the high nobility and the political leaders of the past will become obvious when studying some of the larger sets of tapestries that have survived.

A set of four tapestries, now in the Museo Parroquial in Pastrana, for example, celebrates the victory of the Portuguese King and his troops over the Moroccans in The Taking of Tangier of $1471 .{ }^{34}$ These tapestries were probably commissioned shortly after the North-African campaign and were executed by Pasquier Grenier, one of the leading master weavers from Tournai. The tapestries contain realistic portraits of the King of Portugal, Dom Alfonso I and Prince Dom Joao and it has been suggested that this set of tapestries was commissioned to document this event in the best medium available, in order to glorify the achievements of the Portuguese monarchy. ${ }^{35}$ The set as a whole must have been designed with a fairly large hall in mind, as this tapestry alone measures 3.6 by 10.5 metres. The sheer size as well as the quality of the materials used, in this case wool and silk, leave no doubt about the significance of this particular commission. These tapestries most definitely carried a larger price tag than the two Altarpiece Tapestries mentioned earlier.

When I discussed the role of the art market at the beginning of my paper I called the production of hand-woven tapestries a luxury industry. There are 
two main reasons why these highly-valued textiles were among the most expensive export items produced in the cities of Arras, Tournai, Brussels and Bruges. Firstly, the making of a tapestry has always been extremely labour intensive, especially if the tapestry is of a very high quality. Quality is here defined in terms of the fineness of the weave and the complexity of the design. ${ }^{36}$ The second reason for the costliness of these objects lies in the use of expensive raw products including dyestuffs, as well as wool, silk and increasingly silver and gold threads. A large proportion of the raw material had to be imported from England, Spain Italy and Turkey which increasingly lead to the involvement of financially strong entrepreneurs who owned the necessary capital to provide the weavers with these raw products. ${ }^{37}$ Only in 1500 did Bruges and Antwerp start to produce their own silk in order to become less dependant on imports. ${ }^{38}$

A typical example for the lavishness for many of these woven artifacts is a tapestry which represents Mary as the Source of living Water ${ }^{39}$ It is made of wool, silk, gold and silver threads. A tapestry showing The Coronation of the Virgin and related scenes is even more sumptuous. Because of the high percentage of gold threads this set of tapestries, which depicts The Triumphs of the Mother of God, has been called tapis d'or or Golden Tapestries. ${ }^{40} \mathrm{~A}$ whole set of these golden tapestries was bought in 1502 by Joanna the Mad, the wife of Philip the Fair, from the merchant and tapestry maker Pieter van Aelst. ${ }^{41}$

Because of the lavishness of these tapestries only the very rich could afford these luxury items. Among the clientele of well-known tapestry merchants such as Pasquier Grenier ${ }^{42}$ from Tournai and Pieter van Aelst from Brussels were the high nobility and leading members of the clergy. Whole sets of tapestries with religious or secular themes could be found in the possession of Duke Philip the Good, Emperor Charles V, Pope Leo X and Bernard Cles, the Archbishop of Trente. ${ }^{43}$ High ranking women such as Margaret of Austria, Joanna the Mad and Isabella of Castille, were equally keen on commissioning and collecting these treasured pieces. ${ }^{44}$ Before discussing the situation of weavers in Brussels in more detail, I will take a closer look at how these tapestries were used and by whom.

Given the fact that tapestries were very valuable objects, it is not surprising that they were often used as wall decorations on festive occasions. Tapestries provided comfort and gave the living quarters of wealthy noblemen an atmosphere of style and lavishness. The January calendar picture from the Très Riches Heures de Jean de Berry, ${ }^{45}$ shows tapestries and precious textiles served as decoration for the New Year's celebrations. The wall of the banquet hall was covered with a colourful tapestry depicting scenes from the Trojan War. The tapestry depicted in Jean de Berry's illuminated manuscript had been decorated with inscriptions. A later tapestry from the last-quarter of the fifteenth century, which probably 
belonged to Ferdinand I of Naples, ${ }^{46}$ depicts not only the same subject matter but also contains explanatory inscriptions at the top of the scene. Tapestries depicting the adventures of legendary heroic figures such as Cesar and Alexander were very popular among the rulers of the past, as they identified with their heroic deeds or even believed themselves to be the descendants of these historic or mythical figures. ${ }^{47}$

The tapestries which belonged to Ferdinand I of Naples represent one of five full sets depicting The War of Troy, all of which were woven in Tournai and subsequently delivered to major courts of Europe ${ }^{48}$ In 1472 the cities of Bruges and Tournai presented Duke Charles the Bold with the first set of tapestries. Henry VII of England received another set in 1488 and Charles VIII of France used yet another one for the decoration of his castle in Amboise on the occasion of his marriage to Anne de Bretagne. ${ }^{49}$ The King of Hungary, Mathias Corvinus, did not want to fall behind and joined the club in 1495.

Coming back to the January miniature it seems as if Duke Jean de Berry was not alone in his desire to surround himself with accounts of classical warfare executed in the most appropriate and the most expensive medium available at the time. His interest in precious textiles can further be observed right behind the duke in the canopy above the fireplace which is covered with Berry's armorial devices, the swan, the bear and the fleur-de-lis. These woven canopies were very popular indeed, and many illustrations provide proof of the use of these decorative baldachins on important occasions. According to late medieval court etiquette, such canopies served the purpose of singling out a person of high social standing. On the opening miniature to the Girart de Roussillon manuscript in Vienna, ${ }^{50}$ Duke Philip the Good is also depicted underneath such a canopy or ciel. The canopy is again decorated with his coat of arms and costly golden ornamentation.

Displaying the shield and the heraldic animal of one's ancestors was very important for the nobility of the day and no opportunity was missed to display the symbols of one's lineage, be it on the occasion of a tournament, a marriage or a triumphal entry. The popularity of heraldic ornamentation can be gauged from the quantity of heraldic tapestries in inventories of the time. Many examples of heraldic tapestry have survived such as the large tapestry in the Historisches Museum in Bern which once belonged to Duke Charles the Bold. ${ }^{51}$ It is a good example of what is generally called millefleur tapestry, an ornamental style of decoration with plant and animal motives, frequently used by tapestry weavers from Brussels. ${ }^{52} \mathrm{~A}$ different style of heraldic tapestry was available in the early sixteenth century and has been linked to the city of Enghien. ${ }^{53}$ One example of this group shows the coat of arms of Margaret of Austria, the grand-daughter of Charles the Bold, together with the shields of her parents and grandparents. ${ }^{54}$ The inventory of the palace of Margaret of Austria, dating from 1523/4, lists 19 tapestries with the coat of arms of this woman who governed the Netherlands until her death in $1530 .^{55}$ 
The Dukes of Burgundy and their relatives from the house of Hapsburg were constantly dealing with tapestries, either as luxury items for their own collections or as diplomatic gifts for political allies and relatives. In 1510, for instance, Margaret of Austria bought eight tapestries from the master weaver Arnould Poissonier in Tournai. This set was sold to her for the price of $£ 1,460$ pounds and represented the remarkably modern theme of The Triumphs of Caesar. ${ }^{56}$ It looks as if Margaret had not purchased these tapestries for her own collection, as they appear neither in the inventory of 1516 nor in that of $1523 / 4$. These circumstances as well as the subject matter, unusual for Margaret's taste, suggest that she used this set as a gift, possibly for a male member of the Burgundian-Hapsburgian dynasty. In an earlier inventory drawn up in 1499 at the time of her departure from Spain we find a further reference to a classical theme namely The Story of Hercules. ${ }^{57}$ This design had been chosen as decoration for a bed consisting of a canopy, a head and a side part as well as a bedspread, all made of tapestry rich in gold. ${ }^{58}$ This elaborate ensemble had been brought to Spain from Flanders by Margaret of Austria herself, probably for her own marital bed. What happened to this particular piece after her return to Flanders is not clear, as it does not re-appear in any of the later inventories. At least ten of the twenty-two tapestries, which had been given to Margaret by her mother-inlaw, Queen Isabella of Spain and which are also described in this inventory, can be identified with objects listed in the later inventories which document her collection in Mechelen. These tapestries, which represented The story of Saint Helena, ${ }^{59}$ The Story of Alexander the Great ${ }^{60}$ and The Credo,${ }^{61}$ turn up in the inventories of 1516 and of 1524 with a clear indication of their provenance from Spain.

Such highly treasured pieces were often kept in the family for generations. Joanna the Mad, Margaret of Austria's sister-in-law, for example, had bought four of the Golden Tapestries as a gift for her mother, Queen Isabella of Spain. ${ }^{62}$ When Isabella died in 1504 the same set of tapestries was bequeathed back to Joanna and thus entered her own collection. ${ }^{63}$ It is therefore not surprising that individuals such as Margaret of Austria possessed so many of these costly and often very large tapestries. The two inventories of Margaret of Austria's art collection in Mechelen list in all 95 pieces of figurative tapestry. It is interesting to note that she had by far more more representational than heraldic or decorative tapestries. ${ }^{64}$ Among the representational tapestries listed we can find a broad range of religious and a few literary themes such as the Cité de Dames series. Among the most valuable tapestries described in the inventory, namely those made with silk, gold and silver threads, were a set of four with the old testament story of Esther and a set of three tapestries depicting The Story of Alexander the Great; the latter one has already been discussed. One of the more unusual pieces in this collection was a portrait of Margaret of Austria, which had been 
woven apres le vif. ${ }^{65}$

Apart from the large sets, which were used as wall hangings, the inventory also lists a canopy made in the same technique with a depiction of God the Father and the Holy Ghost ${ }^{66}$ and several more utilitarian pieces such as fourteen textile covers for benches and six cushions made in the same technique. ${ }^{67}$ In the case of the elaborate canopy we are told the name of the artist who made this piece of tapestry, namely Pieter de Pannemaker from Brussels. The weaver and tapestry merchant Pieter the Pannemaker had been appointed court artist by Margaret of Austria on 20 January $1522 .{ }^{68}$ In the fourteenth and fifteenth century it was quite common to bind a painter or book illuminator to one's personal court by appointing him Varlet de Chambre or giving him an equivalent title. ${ }^{69}$ Artists who were priviledged to be attached to the court were either put on the payroll, like Pieter de Pannemaker, or were paid an annual pension. Appointing a tapestry weaver to the court, however, can be described as a fairly recent development. It became more and more important for the high nobility to employ a tapestry maker on a more permanent basis, because of the large number of tapestries in their collections and because rulers such as Charles V and Philip the Fair insisted on taking their tapestry sets with them when going on diplomatic journeys. ${ }^{70}$ In some instances court artists became closely attached to these ruling dynasties, in so far as painters and tapestry makers were frequently taken over from one member of the family to the next. Duverger describes in some detail how highly-regarded artists such as Bernard van Orley coaxed Margaret of Hungary, Margaret of Austria's successor, into employing him as a court painter by presenting the new ruler with gifts. ${ }^{71}$ In choosing the tapestry maker Pieter de Pannemaker, Margaret probably followed the example of her father Emperor Maximilian I and her brother Philip the Fair. Maximilian had appointed Pieter van Aelst tapestry master in the lastquarter of the fifteenth century. ${ }^{72}$ On 8 July 1502 Archduke Philip the Fair made a similar decision by appointing Pieter van Aelst to become his personal tapestry maker. ${ }^{73}$ Van Aelst had accompanied the young prince on his trip to Spain and consequently made several tapestries for Philip and his wife, Joanna the Mad. Pieter van Aelst and Pieter de Pannemaker were not only two of the most famous tapestry weavers from Brussels but also acted as merchant-entrepreneurs ${ }^{74}$ which may be one of the reason why they were chosen as court artists.

As I mentioned at the beginning of my paper, different professions and different art forms were not practised independently from one another, which makes it necessary to look more closely at the collaborative process of making these tapestries, one of the most interesting aspects in the production of tapestries. Collaboration involved a number of artists with different skills and responsibilities. Up to five different parties could contribute to the complex process, although this was not necessarily always the case. In the 
process of tapestry-making, the role of tapestry merchants such as Pasquier Grenier or Pierre Delos was often a crucial one. The merchant was frequently the person who made the first contact with a client and who provided the weavers with the raw materials and the cartoons for their tapestries. ${ }^{75} \mathrm{As}$ was the case in other media, for instance book illumination, the merchant often acted as an agent who supervised the whole process and who sub-contracted work. It was not unusual at all for master weavers, such as de Pannemaker and van Aelst, to participate in such transactions. ${ }^{76}$

That the process of making hand-woven tapestries was indeed a complex one can be seen from the various steps which had to be taken to produce a wall-hanging. Two different painters were usually involved in producing the different types of cartoons required by the weaver. ${ }^{77}$ One artist would make a sketch or a small drawing, generally called the small cartoon or petit patron. Among the earliest surviving examples of such a preparatory drawing are the designs which were used for the already-mentioned tapestry set displaying The War of Troy ${ }^{78}$ In this case we are fortunate to have eight of the original petits patrons dating from about 1465 . While the size of such preparatory drawings remained small, the style changed depending on the time of execution and the personal manner of an individual artist. ${ }^{79}$ Further examples of a 'small cartoon' can be found in the oeuvre of Bernard van Orley, the court painter of Margaret of Austria. ${ }^{80}$

After the first design had been provided by a senior artist like Bernard van Orley, a second artist, in most cases a painter specialised in making accurate scale cartoons, would then enlarge the preliminary design and add filling ornaments, such as plants or clouds, in order to avoid blank spaces in the finished tapestry. ${ }^{81}$ The full-sized cartoon was then placed under the warps of the loom, so that the weaver could see the design while working on the tapestry. In Brussels, all weavers used low-warp looms, generally working from the backside of the finished tapestry. ${ }^{82} \mathrm{~A}$ tapestry fragment in the Museum of Fine Arts, Boston, depicts Penelope at the Loom with a bobbin in her right hand, using a low-warp looms as was the custom in the Burgundian Netherlands. ${ }^{83}$ The last step in the production of a piece of hand-woven tapestry occurred after the tapestry was completed by the weaver. The finished product was then examined by another artisan, the retoucheur or lusteur, whose job it was to correct mistakes or to touch up weak colours. ${ }^{84}$

The Legend of Herkenbald tapestry in Brussels is one of the few tapestries whose history of production is well documented and I will discuss this piece in more detail in order to illuminate the process of production I have so far described in more general terms. ${ }^{85}$ In the case of the Herkenbald tapestry, we know not only the date of execution and the names the artists involved, but also the sum these people received for their work. In 1513 the 'Confraternity of the Holy Sacrament' paid three different artists for a tapestry which had 
been commissioned for the chapel of this brotherhood in the church of Saint Peter in Louvain.$^{86}$ A master from the painters guild of Brussels, called Jean de Bruxelles was paid two-and-a-half Rhenish Guilders and two jugs of wine for providing the petit patron. Another artist, Philippe the painter, was given the relatively high sum of thirteen-and-a-half Rhenish Guilders for transforming the preparatory drawing into a one-to-one scale drawing. ${ }^{87}$ On top of that he was given ten sous for taking the cartoon to Louvain in order to put it up in the church of Saint Peter for examination. Finally, Leon, the weaver from Brussels, was given thirty-two Rhenish Guilders for weaving the tapestry and twenty sous for preparing the decorative borders. ${ }^{88}$ The amount received by the weaver Leon de Smet seems to have been for hours worked only and not for the material used. It is surprising to learn that he earned only half the amount of the two painters involved, despite the fact that he probably spent more time on his task. This could be interpreted as an expression of the relative value attributed to work of the weaver in the process of making a tapestry. The pay may also reflect the tensions which surfaced in the second-half of the fifteenth century between the members from the painters' and the tapestry weavers' guilds. The apparent difference in pay and responsibility is an interesting issue which deserves further attention.

Compared with the guild of painters in Brussels, the weavers' guild was established at a much later point in time. In 1447 the weavers became independent from the wool trade, formed their own guild and issued their own set of rules in $1451 .^{89}$ Until 1476, weavers in Brussels were allowed to produce their own cartoons. ${ }^{90}$ Occasionally they purchased cartoons from journeymen who were passing through the city. This practice caused dismay among the painters of Brussels and in 1476 an order was given that only members of the local painters' guild were allowed to make representational cartoons. From then on, weavers were not permitted to make their own cartoons except for millefleur and verdure tapestries, in other words designs for less important tapestries involving animals, flowers or greenery. These kinds of settlements between different guilds in the same town were not unusual in the late-fifteenth and early-sixteenth century. Similar regulations can be found in the context of mass-produced carved altarpieces, which were also manufactured in a collaborative effort by different guilds, in this case involving painters, sculptors and carpenters. ${ }^{91}$

Another similarity between the production of carved altarpieces and sumptuous tapestries is the general concern about quality control and the protection of the local product against fraudulent imitators from other cities. Between 1450 and 1472, completed tapestries had to be presented in the Chapel of Saint Christopherus where they would receive the seal of approval from the guild. ${ }^{92}$ In 1472 , a change to the inspection process was introduced, resulting in the finished product being examined while still on the loom in 
the studio of the weaver. This regulation made sure that tapestries from outside Brussels could not be smuggled into town in order to be presented to the jury as a local product. Finally, in May 1528 the magistrate of Brussels ruled that each tapestry which measured more than six square yards should be provided with a small red shield and the letters $B B$, so that the tapestry could be identified as a product from the city of Brussels in Brabant even after it had left the town. ${ }^{93}$

These decrees indicate that the competition in the tapestry trade of the time must have been quite stiff and that the magistrate and guilds of Brussels were anxious to ensure their position in this lucrative business. While these considerations shed some light on the collaboration between weavers and painters, it does not explain why tapestries like The Legend of Herkenbald were desired by a religious community such as the Brotherhood of the Holy Sacrament. In the past, this wealthy confraternity had commissioned a number of artworks for the furnishing of its two chapels and the ambulatory of the church of Saint Peter in Louvain. ${ }^{94}$ After having erected a 12 metre high sculptured sacrament tower for the protection of the consecrated host, ${ }^{95}$ the Brotherhood also commissioned a large painted triptych from Dieric Bouts in honour of the Holy Sacrament. In 1513, the same Brotherhood decided to acquire another artwork with a eucharistic subject matter for their chapel, this time a Golden Tapestry, which was even larger in size than the Holy Sacrament altarpiece by Dieric Bouts. ${ }^{96}$ The topic chosen by the confraternity, The Justice of Herkenbald, had become popular through two similar commission in the city of Brussels. ${ }^{97}$ By 1460, the legend of Herkenbald had already been portrayed in the medium of tapestry, together with two other stories related to justice, The Legend of Pope Gregory the Great and The Justice of Emperor Trajan. The design of this tapestry was based on four famous panel paintings by Rogier van der Weyden, the official painter of the city of Brussels. ${ }^{98}$ Unfortunately, van der Weyden's Justice panels in the town hall of Brussels were destroyed in the seventeenth century. The ten-and-a-half meter long tapestry in the Historical Museum of Bern still attests to the importance of Rogier's painting for the city of Brussels. ${ }^{99}$ It has been shown that the tapestry reflects the composition of the original paintings fairly accurately. The explanatory inscriptions, for instance, which had been painted on the original frames of van der Weyden's paintings, were integrated word by word into the tapestry, this time in the form of woven scrolls. It has been suggested by Schneebalg-Perelmann that Rogier van der Weyden was not just employed to paint pictures for the city of Brussels, but that he was also responsible for producing cartoons for important tapestry commissions. ${ }^{100}$

That van der Weyden's paintings were indeed very popular among weavers and served as models in more than one case can be seen from a group of tapestries, which are based on Rogier van der Weyden's Saint Luke 
painting the Virgin a painting dating from about $1440 .{ }^{101}$ The inversion of the original design, which is a common feature in tapestries, can be explained by the technique of using low-warp looms. The Virgin is now holding the Christ child in her left arm and is sitting on the right side of the painting. The figure of Saint Luke, on the other hand, has been modified to accommodate the technical requirements of the new medium. ${ }^{102}$ In both examples, the painting and the tapestry, Saint Luke is therefore creating the image of the Virgin with his right hand. It can be assumed that a cartoon painter was called in to prepare a preliminary drawing, firstly because the tapestry is twice as big as the panel painting and secondly because the tapestry reveals minor variations. The open sky, for instance, has been replaced by trees and larger buildings, Mary's bench has been embellished with further wooden carvings and the room filled with more decorative details, a basket, a vase and a stool. ${ }^{103}$ The woven frame as well as the spaciousness of the main scene give the woven artefact a more painterly appearance.

This tapestry is a good example of the trend towards a more painterly style in tapestries at the turn of the century. ${ }^{104}$ This development, which radically changed the style of tapestries, can be explained by two factors, the improvement of dying techniques, which led to a wider range of colours in the raw material used, and the stronger influence of the painters guild from 1476 onwards. As mentioned earlier, after that date only members of the painters guild were allowed to produce cartoons for representational tapestries and it looks as if painters were quite well paid for this service. Often these cartoons were kept in the workshop for a long time and were used over and over again which may be one reason for cartoons being so expensive in the first place.

The most famous example for re-cycling the same design is probably The Acts of the Apostles series, a set of tapestries which had been commissioned by Pope Leo X for the decoration of the Sistine Chapel and which was woven by Pieter van Aelst and his workshop after cartoons by Raphael and his pupils. ${ }^{105}$ Also in this case the original design by Raphael has been reversed in the finished tapestry. The first series of tapestries was completed under the supervision of Pieter van Aelst in 1521, only six years after the tempera paintings by Raphael had been sent to Brussels. Soon after these tapestries were displayed in the Sistine Chapel, the design became so popular that two further sets were made, one for Emperor Charles $\mathrm{V}$ and one for Cardinal Ercole Gonzaga. When Pieter van Aelst died in 1532, the cartoons must have been passed on to the next generation of weavers, which explains why the Mantua set from 1540 looks identical but bears the monogram of Jan van Tieghem and Leo van den Hecke. ${ }^{106}$ While the central image remained the same in each new set, the border decoration varied according to the requirements of the patron and the taste of the period in which each particular tapestry was made. The earlier version of The Miraculous Draught 
of Fishes, for instance, carries the Papal coat of arms in the top-left and the top-right corner and depicts scenes from the life of Pope Leo on the lower border. ${ }^{107}$ The later version on the left bears the shield of Cardinal Gonzaga and has been provided with a different set of border decorations.

It was quite common among tapestry weavers in Brussels to borrow or lend cartoons for specific purposes, a practice which can also be observed in contemporary panel paintings, as recent research on Gerard David and workshop practices in Bruges has shown. ${ }^{108}$ This practice was unlikely to have extended beyond city boundaries. As the magistrate of Brussels was quite concerned about foreign workshops which tried to imitate their tapestries and thus competed with the local product, the city made an effort to protect its designs wherever possible. We know of one instance where the magistrate decided to burn several cartoons which had been drawn illegally after the Justice panels by Roger van der Weyden. ${ }^{109}$ That way the city ensured that Rogier's design could only be used by artists from Brussels, almost claiming copyright for a painting which had been produced by their official painter some fifty years before. The popularity of tapestries made after designs by Rogier van der Weyden or Raphael has provided some indication of the significance of this medium as an art form in its own right during the fifteenth and sixteenth centuries. The appreciation of tapestries as an important form of artistic expression depends in part on an awareness of the increasing input of painters into the complex process of production.

In conclusion we can say that the wide distribution of sets of tapestries such as The Acts of the Apostles and The War of Troy illustrate the importance of hand-woven tapestries for the general trade in luxury goods, which had become such an important factor of the art market in the Burgundian Netherlands. The rules and regulations which were put forward by guilds and cities to control the quality of tapestries and to protect the manufacturers from outside competitors demonstrate the growing significance of this branch of the art industry. The conflicts between the different guilds concerning the right to provide the cartoons equally show that this was an area of artistic production which provided a steady source of income for both painters and tapestry weavers.

From the examples given in this paper it becomes apparent that tapestries were particularly popular among the high nobility. Complete sets of tapestries as well as single pieces could be found in the collections of kings and dukes, popes and cardinals. Towards the end of the fifteenth century this interest in collecting tapestries was taken up by the wealthy middle class whose members began to commission tapestries, albeit in a much more modest fashion. Complete tapestry sets such as The War of Troy and The Acts of the Apostles were in many cases bought for reasons of prestige and ostentation. While hand-woven tapestries may have been collected by some for their material value, one should however not underestimate the fact that 
they were also valued for their distinct aesthetic qualities. A tapestry from the The Story of Jacob series by Bernard van Orley exemplifies the progress made with respect to a more painterly style. ${ }^{110}$ The intricacy of the design and the pictorial quality of such pieces leave no doubt that tapestries were also bought for aesthetic reasons. The above-mentioned development towards a more painterly style which could be observed in the second-half of the fifteenth century contributed considerably to the popularity of this medium. This trend which has been explained by the increasing influence of painters in the design process, culminated in the work of Bernard van Orley, Margaret of Austria's court painter, who worked in close collaboration with the major tapestry workshops in Brussels. He provided the designs for a large number of important commissions, such as The Battle of Pavia tapestries and The Story of Jacob series. I have repeatedly stressed the fact that the themes chosen for major sets of tapestries are also worth studying. They frequently interpret popular themes in a programmatic complexity and a quality which is equal to contemporary panel paintings. Apart from representing traditional religious subjects, tapestries often depict new themes which are of political significance or reflect the literary taste of a patron. The wealth of material which is stored in archives and museums is testimony to the important historical role these art works once played and study of it could eventually lead to a re-evaluation of the place of tapestries in the history of Northern Renaissance Art.

Dagmar Eichberger

Department of Fine Arts

University of Melbourne

\section{NOTES}

1 F. Salet, David et Bethsabée, Editions de la Réunion des Musées Nationaux, Paris, 1980, and, Tapisseries bruxelloises de la Pré-Renaissance (exh. cat.) Musées Royaux d'Art et d'Histoire, Brussels, 1976, cat. nos. 1-10, pp. 25-51.

2 Tapestries such as the David and Bathseba cycle often measure several meters in height and width. The scene showing The Act of Adultery and Uriel's Farewell for instance measures $452 \times 816 \mathrm{~cm}$. A colour reproduction of this tapestry can be found in Salet.

3 Reproductions of the Story of Jacob series can be found in Roger d'Hulst, Tapisseries Flamandes du XIVe au XVIIIe siècle, Editions L'Arcade, Brussels 1960; reproductions of the Acts of the Apostles series can be found in $\mathrm{J}$. Shearman, Raphael's cartoons in the Collection of her Majesty the Queen and the tapestries for the Sistine Chapel, London, 1972.

4 J. Snyder, Northern Renaissance Art. Painting, Sculpture, the Graphic Arts from 1350-1575, Harry N. Abrams, New York, 1985.

5 An interesting article by Moyano, for instance, discusses the shaping of the Altes 
Museum as a temple for high art exclusively. See St. Moyano, 'Quality versus History, Schinkel's Altes Museum and Prussian Arts Policy', Art Bulletin LXXII, 4 (1990), pp. 585-608; for the development of museums in general see G. Bazin The Museum Age, New York, 1967 and the introduction in V. Jackson (ed.) Art Museums of the World, Greenwood Press, Westport, Conn. 1987.

6 Reproductions of the Battle of Pavia can be found in d'Hulst. An unknown canvas painting of the Battle of Pavia is listed in the Vienna inventory of Margaret of Austria.

7 The most notable exception to the rule is probably the cycle of history paintings commissioned in the second quarter of the fifteenth century by Duke Wilhelm IV of Bavaria and his wife Jacobaea of Baden for their residence in Munich; see Alte Pinakothek München, Bayrische Gemäldesammlungen, Munich, 1986, pp. 12-16.

8 The question of who were the clients and patrons of artists such as Jan van Eyck and the other protagonists of early Netherlandish art has been dealt with in some detail by Snyder and more recently by Craig Harbison, Jan van Eyck. The Play of Realism, Reaktion Books, London, 1991.

9 Walter Prevenier/Wim Blockmans, The Burgundian Netherlands, Cambridge University Press, Cambridge, 1986.

10 ibid., pp. 9-26.

11 ibid., p. 32, map B on page 391.

12 ibid., pp. 48-58; see also R. Doehaerd, W. Blockmans et al., Histoire de Flandre des Origines à nos jours, La Renaissance du Livre, Brussels, 1983.

13 Sophie Schneebalg-Perelman, 'Die Brüsseler Teppichwirkkunst zur Zeit Philipps des Guten' in Rogier van der Weyden - Roger de le Pasture, Stadtmaler von Brüssel, Porträtist des burgundischen Hofes (exh.cat.), Stadmuseum Brüssel, Maison du Roi, Brussels, 1979, p. 104; see also Prevenier/Blockmans, pp. 92-96.

14 Erik Duverger, 'The Middle Ages, Tapestry and Textile Art', in H. Liebaers, V. Vermeersch, L. Voet et al, Flemish Art from the Beginning till Now, Alpine Fine Arts Collection, London, 1985, p. 189.

15 M. Jarry, 'Tapestry', in The New Encyclopedia Britannica, 15th ed., Chicago, 1983, vol. 17, pp. 1055-1067.

16 Schneebalg-Perelman, p. 104.

17 Snyder, pp. 41-73; also G. Troescher, Burgundische Malerei, Gebr.Mann Verlag, Berlin, 1966.

18 See J.M. Montias for a discussion of the most important contributions to this question to date, J.M. Montias, 'Socio-Economic Aspects of Netherlandish Art from the Fifteenth to the Seventeenth Century, a Survey', Art Bulletin LXXII, 3 (1990), pp. 358-373.

19 Dan Ewing, 'Marketing Art in Antwerp, 1460-1560, Our Lady's Pand', in Art Bulletin, LXXII, 4 (1990), pp. 558-584.

20 Lynn Jacobs, 'The Marketing and Standardization of South Netherlandish Carved Altarpieces, Limits to the Role of the Patron', in Art Bulletin, LXXI, (1989), pp. 203-229.

21 See J.C. Wilson, 'The Participation of Painters in the Bruges Pandt Market, 1512-1550', Burlington Magazine, CXXV, (1983), p. 479; see also Montias, p. 369.

22 Petrus Christus, Saint Eloy in his Workshop, New York, Metropolitan Museum, 
Robert Lehman Collection, see Snyder, colour plate 26, also J. Upton, Petrus Christus, his place in fifteenth century Flemish painting, Pennsylvania State University Press, 1989.

23 D. Ewing, Marketing Art in Antwerp (1990), p. 559.

24 A reproduction of a typical cloth market can be found in W. Prevenier/W. Blockmans, p. 93, fig. 79 .

25 Ewing, p. 559.

26 ibid., pp. 580-1.

27 ibid., pp. 559-563.

28 Jacobs; R.H. Marijnissen, M. Serck-Dewaide, N. Goetghebeur et al., The Antwerp Altarpiece, National Gallery of Victoria, ASLK, Antwerp, 1983.

29 Saint Luke painting the Virgin Paris, Louvre; see, Rogier van der Weyden Rogier de la Pasture (1979), fig. 35; a slightly different version of the same theme has survived in the Musées Royaux d'Art et d'Histoire, discussed in Jan Van der Stock (ed.), Stadtbilder in Flandern, Spuren bürgerlicher Kultur 1477-1787, Gemeindekredit, Brussels, 1991, pp. 394-396.

30 Jarry, p. 1061.

31 The tapestry showing Saint Luke painting the Virgin (Louvre, Paris) measures $225 \times 261 \mathrm{~cm}$.

32 Reproductions of these two examples can be found in E. Duverger, Tapestries and Textile Art (1985), pp. 200 and 201.

33 That these different groups developed indeed a similar taste can be seen from a tapestry in the national collection of Spain Madrid. It is a slightly larger version $(336 \times 404 \mathrm{~cm})$ of the Mass of Saint Gregory tapestry plus additional religious figures and portraits. It was purchased by Joanna the Mad for her mother Isabella of Spain. For further information on this tapestry see Roger d'Hulst, pp. 115-120.

34 Jay A. Levenson (ed.), Circa 1492. Art in the Age of Exploration (exh.cat.), National Gallery of Washington, New Haven/London ,1991, pp. 138-141.

35 ibid.

36 The examples I discuss in the course of my paper range from using 5 warp (e.g. Story of David and Bathseba) to 9 threads per square centimetre (Mass of Saint Gregory).

37 Prevenier/Blockmans, p. 74.

38 ibid., p. 88.

39 See d'Hulst, pp. 97-104..

40 J.A. Levenson, Circa 1492 (1991), p. 155.

41 d'Hulst, p. 120.

42 E. Duverger discusses the role of certain individuals such as Pasquier Grenier in some detail, Tapestries and Textiles (1985), pp. 199-200.

43 d'Hulst, pp.XIV-XXVII.

44 H. May, 'De Kastiliaanse-Boergondische Wandtapijten uit de verzamelingen van Margareta van Oostenrijk', in Overdruck uit de Handelingen van de Kon. Kring voor Oudh., Let. en Kunst van Mechelen dl. LXVII (1963), pp. 67-75; J.M. Massing, 'Arnould Poissonier of Tournai and his '...Huit pièces du triomphe de César' for Margaret of Austria', Artes Textiles 11 (1986), pp. 69-74; Francisco J.S. 
Canton, Libros, tapices y cuadros que coleccionó Isabel la Católica, Consejo Superior de Investigationes Cientificas, Madrid, 1950; G. De Boom, Marguerite d'Autriche-Savoie et la Pré-Renaissance, Librairie E. Droz/ Librairie Falk Fils, Paris/Brussels 1935, pp. 136-7.

45 Musée Condé, Chantilly, ms. 65, fol. 2r.

46 The War of Troy series, Zamora Cathedral, see G.W. Digby, Victoria and Albert Museum, The Tapestry Collection, Medieval and Renaissance, Her Majesty's Stationary Office, London, 1980, p. 17.

47 Massing, p. 74.

48 Digby, pp. 14-18.

49 ibid., p. 15.

50 Österreichische Nationalbibliothek, Vienna, cod. 2549, fol. 6.

51 d'Hulst, pp. 77-86; this tapestry measures $306 \times 687 \mathrm{~cm}$.

52 Schneebalg-Perelman, p. 111.

53 Guy Demarcel, Tapisseries anciennes d'Enghien, Féderation du Tourisme de la Provence de Hainault, Mons, 1980.

54 ibid.

55 'Inventaire des tableaux, livres, joyaux et meubles de Marguerite d'Autriche, fille de Marie de Bourgogne et de Maximilien empereur d'Allemagne, fait et conclus en la ville d'Anvers le XVII. d'avril MVc. XXIIII'. This inventory exists in two copies one in the Bibliothèque Nationale in Paris and one in Vienna; the Paris copy has been published by $\mathrm{H}$. Michelant, 'Inventaire des vaisselles, joyaux, tapisseries, peintures, manuscrits, etc. de Marguerite d'Autriche, régente et gouvernante des Pays-Bas, dressé en son palais de Malines, le 9 juillet 1523', in Académie Royale des Sciences des Lettres et des Beaux-Arts de Belgique, Bulletin 3, ser.v. 12 (2), 1870 , pp. 3-75 and 83-136; the relevant entries can be found in Michelant, pp. 23 and 24.

56 Massing, p. 69.

57 Inventory of 28 Septembre 1499 (Granada), 'Libro de las joyas de oro e plata, perlas y pedras y otras cosas de azienda de la camera de la muy alta y ecelente dona Margarita, princesa de Castilla, las quales se entregaron a su alteza en la cibdad de Granada en beynte e ocho dias de setienbre de nobenta e nuebe anos en presencia de museur de Sanpique e museur de Bere, sus embaxadres, las qualas son las siguientes...', published by Rudolf Beer in Jahrbuch der kunsthistorischen Sammlungen des allerhöchsten Kaiserhauses, 12 (1891), CX-CXXIII. This inventory lists all the objects which were handed over to Margaret of Austria in Granada, after her husband, Dauphin Juan de Castille had died.

58 ibid., no. 223, 'Una cama de tapeceria, en que ay quatro piecas, cielo e cabecera e costado e sombrecama, muy ricos de oro, de la estoria de Ercoles. Dos cortinas de tafetan colorados de dicha cama'.

59 Michelant (note 51), p. 123, 'Item, quatre pieces de tappisserie de Sainct Estayve, sans or ne argent, qui est venue d'Espaigne, garnie de boucran blanc'; A.de Laborde as well as $\mathrm{H}$. Zimmerman have transcribed the name of the Saint as Eslayne, see, A. de Laborde, 'Inventaire des tableaux, livres, joyaux et meubles de Marguerite d'Autriche... fait et conclud en la ville de Anvers 17/4/1524', in Revue Archéologique VII (1850), p. 254; H, Zimmerman, 'Inventoire des parties de 
meubles estans es cabinetz de Madame en sa ville de Malines, estans a la garde et charge de Estienne Luillier, varlet-de-chambre de ma dite dame, lequel en doit respondre a Richard Contault, garde-joyault de ma dite dame, et le dit Contault en tenir compte a icelle ma dite dame' (Inventory of 20 April 1524 - 21 March 1530, partial copy of inventory in Paris which has been published by Laborde and Michelant), published in 'Urkunden und Regesten des K. u.k. Haus-, Hof- und Staats-Archiv', reg. 2979, published by H. Zimmerman, Jahrbuch der kunsthistorischen Sammlungen des allerhöchsten Kaiserhauses, 3 (1885), p. CXXII.

60 Michelant, Inventaire des vaisselles, joyaux, tapisseries...(1870), p. 123.

61 ibid., p. 123, 'Item, trois pieces de tappisseries du Credo, belles et riches, ou il y a de l'or et de la soie, qu'il sont venez d'Espaigne'.

62 d'Hulst, p. 120.

63 Levenson, p.155.

64 Michelant, pp. 24, 25, 123, 125, 128, 129.

65 ibid., p. 85, 'Item, ung aultre riche tableau de la pourtraiture de Madame, fete en tapisserie apres le vif'.

66 ibid., p. 129, 'Item, depuis cest inventoire fait a receu ledit garde-joyaulx ung riche ciel de tapisserie... fait par Pictre Pannemaire a Bruxelles, ouquel est figure Dieu le Pere et le $S(t)$ Esperit, envirennez de plusieurs anges'.

67 ibid., pp. 23, 24, 25.

68 G. de Boom, Marguerite d'Auriche-Savoie (1935), p. 137.

69 Harbison, pp. 19-32; Josef Duverger, 'Het tapijtwerk aan het Hof van Margareta van Ostenrijk', Jaarboek Koninklijke Vlaamse Academie...van Belgie, XXI, p. 151. In his doctoral thesis Josef Duverger has investigated the relationship between patron and artist. His important findings were published posthumously in 'Het statuut van de zestiende-eeuwse hofkunstenaar in de Nederlanden', in Jaarboek, Koninklijk Museum voor Schone Kunsten-Antwerpen, 1982, pp.61-95.

70 Jan-Karel Steepe, 'Inscriptions décoratives contenant des signatures et des mentions du lieu d'origine sur des tapisseries bruxelloises de la fin du XVe et debut du XVI siècle', in Tapisseries bruxelloises de la Pré-Renaissance (exh.cat.), Musées Royaux d'Art et d'Histoire, Brussels, 1976, p.207.

71 J. Duverger, Het statuut (1982), p. 64, for other examples see footnote 20.

72 Levenson, p.155. Margaret of Austria had two tapestry weavers on payroll, Pieter de Pannemaker and Pieter Nieuwland (one stuiver each per day). Apart from this more formal arrangement she also dealt on a more casual basis with two weavers from Edingen, L. Flascoen and Hendrik van Laeken, and with a number of tapestry merchants such as J. Hertsteen, A. Poissonier and Pieter van Aelst; see J. Duverger, Het statuut (1982), p. 82 and J. Duverger, Het tapijtwerk (1959), pp. 151-152.

73 d'Hulst, p. 120.

74 J.-K. Steppe, Inscriptions décoratives (1976), pp. 215-216, Steppe mentions two additional weavers, Antoine Grenier and Arnould Poissonier, who also acted at the same time as merchants.

75 Prevenier/Blockmans, pp. 73-75.

76 Steppe, pp. 222-223. 
77 ibid., p. 223.

78 It is the size and the closeness to the final appearance of the tapestries which has lead to the conviction that these drawings must have been the preparatory designs. The drawings in Paris measure $31 \times 57 \mathrm{~cm}$, the final tapestry $416 \mathrm{~cm} \mathrm{x}$ $737 \mathrm{~cm}$; see pls. $12-14$.

79 On the interpretation of the different drawings which relate to The Hunts of Maximilian tapestries in the Louvre see N. Beets, 'Zestiende-eeuwensche Kunstenaars, II. Barent van Orley, Twee eigenhandige ontwerpen van Barent van Orley voor de Tapijtserie der Belles Chasses de Maximilien', Oud Holland, XL, VIII (1931), pp. 145-171; also R. Bacou, Drawings in the Louvre, the German, Flemish and Dutch Drawings, London, 1968, cat. no. 38 and 39.

80 Maryan Wynn Ainsworth, "Bernart van Orley, Peintre-Inventeur", Studies in the History of Art, National Gallery Washington, vol.24 (1990), pp. 41-64.

81 Schneebalg-Perelman, p. 108.

82 Steppe, p. 219, see also E. Duverger, Tapestries and Textiles (1985), p. 89.

83 Prevenier/Blockmans, p. 77.

84 Steppe, pp. 219-221.

85 The Legend of Herkenbald, Musées Royaux d'Art et d'Histoire, Brussels, see Tapisseries bruxelloises de la Pré-Renaissance (1976), cat. no. 19, pp. 78-83.

86 ibid., p. 80.

87 ibid., p. 82.

88 ibid.

89 Schneebalg-Perelman, p. 110.

90 ibid., p.111; see also, d'Hulst, p. XX.

91 Jacobs.

92 Steppe, p.193.

93 ibid. these two letters can be found on many tapestries from this period, for instance on Bernard van Orley's Story of Jacob series in the Musées Royaux d'Art et d'Histoire, Brussels.

94 Shirley Neilson Blum, Early Netherlandish Triptychs, a Study in Patronage, Berkeley/Los Angeles, 1969, pp. 59-70.

95 H. Liebaers et.al., Flemish Art (1985), p. 85.

96 The triptych by Bouts measures $192 \times 312 \mathrm{~cm}$, the Herkenbald tapestries measure of $387 \times 430 \mathrm{~cm}$.

97 d'Hulst, pp. 59-70; see also G. Demarcel, 'La légende d'Herkenbald et la justice de l'empereur Trajan. Notice iconographique', Tapisseries bruxelloises de la Pré-Renaissance (1976), pp. 243-253.

98 E. Panofsky, Early Netherlandish Painting. Its Origin and Character (1953), Icon edition, New York, 1971, pp. 264/5.

99 A.M. Cetto, Der Berner Traian-und Herkenbald-Teppich, Bern, 1966.

100 Schneebalg-Perelman, p. 104.

101 Rogier van der Weyden - Roger de le Pasture (1979), cat.no.35, pp. 172-173;

102 Schneebalg-Perelman, p. 172.

103 ibid.

104 E. Duverger, Tapestries and Textiles (1985); Schneebalg-Perelman, p. 111; for the discussion of a more pictorial style in tapestries also see, M.A. Ainsworth, 
Bernart van Orley, Peintre-Inventeur (1990), p. 41.

105 Sophie Schneebalg-Perelman, 'Un nouveau regard sur les origines et la developpment de la tapisserie bruxelloise du XIVe siècle à la pré-Renaissance', Tapisseries bruxelloises de la Pré-Renaissance (1976), pp. 185-187; on the actual cartoons see J. Shearman, Raphael's cartoons in the Collection of her Majesty the Queen (1972).

106 M. Hennel-Bernasikowa, Eric Duverger, Ryszard Szmydki, G. Demarcel, Vlaamse wandtapijten uit de Wavelburcht te Krakau en uit andere Europese verzamelingen (exh.cat.), City of Gent, Ghent, 1988, pp. 72-83.

107 Schneebalg-Perelman, p. 187.

108 J.C. Wilson, 'Connoisseurship and Copies, The Case of the Rouen Grouping', Gazette des Beaux Arts, CXVII (1991), pp. 191-206.

109 Schneebalg-Perelman, p. 108.

110 d'Hulst, pp. 183-192. 